\title{
ゲノム編集技術による遺伝子治療のさらなる展開 小野寺雅史
}

国立成育医療研究センター成育遺伝研究部

現在, 遺伝子治療は「疾患の治療や予防を目的として遺伝子又は遺伝子を挿入した細胞を人の体内に投与すること」 と定義され，変異遺伝子はそのままに機能的な遺伝子を新たに追加する方法が採られている。ただ, gain-of-function により発症する疾患やべクター挿入による腫瘍発生の問題もあり, 近年, CRISPR/Cas システムを始めとする遺伝子 編集技術による遺伝子治療の開発が急速に進められている。本稿では, 現行の「Gene additionによる遺伝子治療」の 問題点と今後の展開が期待される「Gene correction による遺伝子治療」に焦点を当て, その有効性, 安全性, さらに はそこに生ずる倫理問題等を考える。（日本造血細胞移植学会誌 $7(2): 32-39,2018$.

\section{緒言}

現在，遺伝子治療は「疾患の治療や予防を目的として遺 伝子又は遺伝子を挿入した細胞を体内に投与すること」と 定義され ${ }^{1}$, その方法として疾患の原因遺伝子はそのまま に機能的遺伝子を新たに患者細胞に追加する方法が採られ ている(Figure 1A 左)。これを Gene addition とよぶが, こ の方法でも難治性遺伝性の多くが一つの遺伝子変異により 病気が発症する単一遺伝子病であり，また，その遺伝形式 として劣性形式を採ることから, 正常遺伝子を患者細胞に 導入し, 機能的タンパク質を発現させることで患者臨床症 状は十分に改善する。事実, アデノシン・デアミナーゼ $(\mathrm{ADA})$ 久損症 ${ }^{2} \mathrm{P} \mathrm{X}$ 連鎖重症複合免疫不全症 $(\mathrm{X}-\mathrm{SCID})^{3}$, ウイスコット・アルドリッチ症候群（WAS $)^{4}$ な゙の原発性 免疫不全症では, 遺伝子治療はその有効性, 安全性を臨床 の場で実証し，ADA 欠損症に至っては 2016 年に欧州にて Strimvelis $^{\circledR}$ として医薬品の承認を受けている。また, 疾患 ごとに適切な前処置を選択することで原発性免疫不全症以 外の遺伝性疾患, 例えば, 副腎白質ジストロフィー $(\mathrm{ALD})^{5}$ や異染性白質ジストロフィー $(\mathrm{MLD})^{6}$, サラセミア7等に対 しても遺伝子治療の有效性, 安全性は証明されている。な お, これら遺伝子治療は患者造血幹細胞を, 一旦, 患者体 外に取り出し, そこでウイルスベクターを用いて遺伝子導 入を行う ex vivo 遺伝子治療であるが (Figure 1B 右)，他に も機能的遺伝子を発現するアデノ随伴ウイルス（AAV）べ クターを直接，患者体内に投与するin vivo 遺伝子治療 （Figure 1B 左）が神経・筋疾患，遺伝性網膜疾患 ${ }^{8}$, 血友 病 ${ }^{9}$, 先天代謝異常症に対して行われ, その有效性, 安全性 が多くの臨床試験の中で検証されている。

たた，gain-of-functionにより発症する遺伝性疾患や目的 遺伝子の発現調節に複雑さを伴う疾患ではこの Gene additionによる遺伝子治療では十分に対応できず，また，使 用するウイルスベクターが時にがん関連遺伝子の近傍に挿 入し, insertional mutagenesisによる造血系腫瘍を発症する ことがある。このような中, 近年, CRISPR/Cas システム を始めとする遺伝子編集技術が格段の進歩を遂げ，さら に, これら遺伝子の運び屋として染色体非挿入型ウイルス ベクターを用いるようになってきたことからヒト細胞への 遺伝子改変効率が格段に向上し, 今後は「遺伝子での治療 (Gene addition)」から, 変異遺伝子を書き換える「遺伝子 への治療（Gene correction）(Figure 1A 右)」にその流れを 大きく変えるものと思われる。

本稿では, Gene addition による ex vivo 遺伝子治療の問題 点を概説し, その問題点の解決策として今後の展開が期待 される Gene correctionによる遺伝子治療の有効性, 安全性, さらにはそこに生ずる倫理面について考える。

\section{1. ex vivo 遺伝子治療における造血系異常}

これまでに造血幹細胞遺伝子治療において白血病を含む

\footnotetext{
Submitted August 14, 2017; Accepted October 14, 2017; Published online, April 16, 2018. (Handling Editor: Yoshiki Akatsuka, Fujita Health University Hospital)

Key words : gene therapy, genome editing, gene addition, gene correction, insertional mutagenesis

Correspondence: Masafumi Onodera, National Center for Child Health and Development, 2-10-1 Okura, Setagaya-ku, Tokyo, 157-8535, Japan. E-mail: onodera-m@ncchd.go.jp dx.doi.org/10.7889/hct-17-014 (C) The Japan Society for Hematopoietic Cell Transplantation.
} 
A

Gene addition

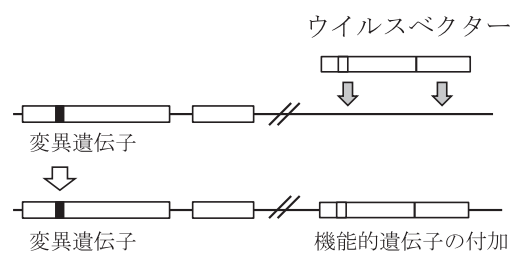

Gene correction

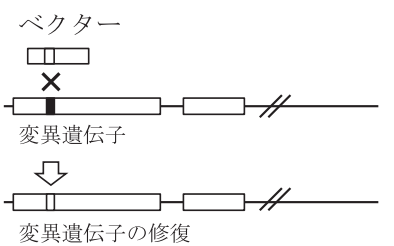

B

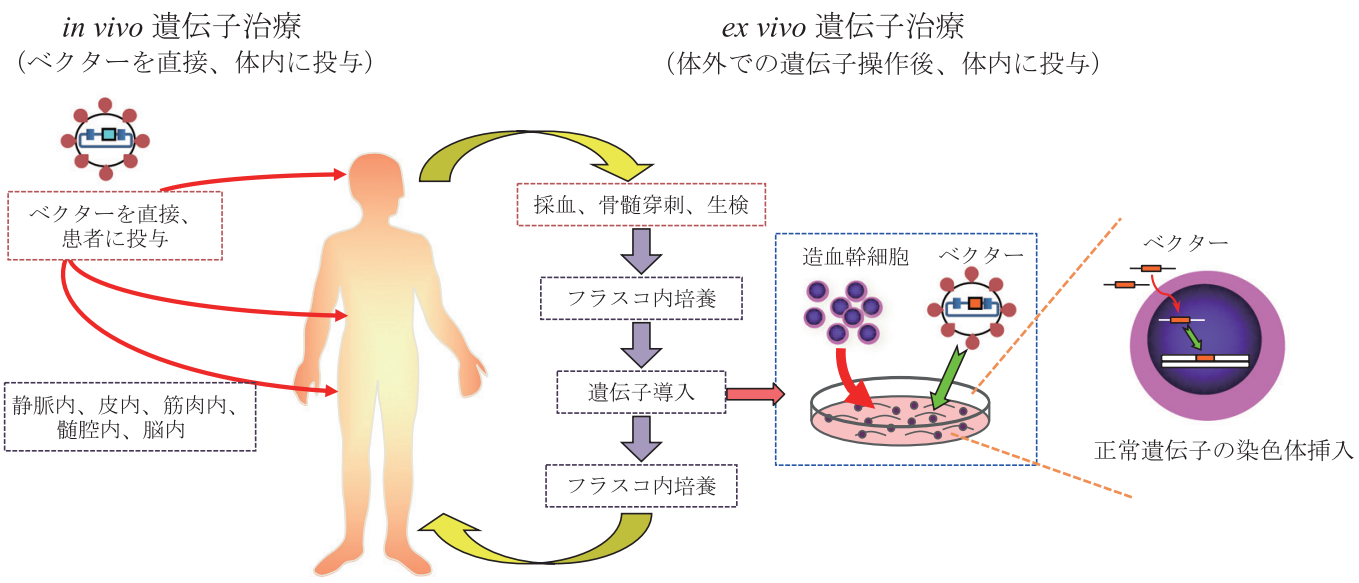

Figure 1. 遺伝子治療の種類. 遺伝子治療には变異遺伝子をそのままに機能的遺伝子を導入する Gene addition (A 左図) と変異遺伝子そのものを修復する Gene correction（A 右図）がある。また, ウイルスベクター等を, 直接, 体内に投与 し, そこでの遺伝子導入を行う in vivo 遺伝子治療と, 標的細胞を一旦, 体外に取り出し, 試験管等で遺伝子を導入し, 再び，患者に投与する ex vivo 遺伝子治療がある。

造血系異常を発症した疾患は X-SCID, WAS, X 連鎖慢性 肉芽腫症（X-CGD）であり，これら全てはマウスに白血病 を発症させるオルソレトロウイルス亜科（ガンマレトロウ イルス属： $\gamma \mathrm{RV} ）$ 由来のベクターを使用したものである。

\section{1) $X-S C I D$}

$\mathrm{T}$ 細胞増殖に関わるサイトカイン（IL-2，4，7，15，21） 受容体の共通鎖 $\gamma_{\mathrm{c}}$ の異常により発症する疾患で, これま でにフランス,イギリスにおいて 20 名の患者に対し造血幹 細胞遺伝子治療が行われ, 17 名に T 細胞新生など一定の治 療効果を上げている。ただ，治療を受けた 5 名に $\mathrm{T}$ 細胞性 白血病が発症し, うち 4 名は $\alpha \beta$ T 細胞型で化学療法にて寛 解したが, 1 名は $\gamma \delta \mathrm{T}$ 細胞型にて死亡している。その㨂入 部位として $L M O-2, C C N D 2, B M I 1$ が上げられるが，白血 病細胞ではこれらべクター挿入以外に染色体転座などの別 の遺伝子変異を認めており, がん関連遺伝子近傍へのべク ター挿入は遺伝子導入細胞にがん化の素因を与えるもの で, クローナルな増殖には新たな遺伝子変異が second hit として必要であることが示唆される。また, 同様の SCID である ADA 欠損症では 40 名を超える患者が $\gamma \mathrm{RV}$ ベクター を用いて造血幹細胞遺伝子治療を受け，患者においては
LMO-2 P MECOM 近傍へのベクター挿入を認めるが ${ }^{10}$, 実 際にはクローナルな増殖は起こっておらず，がん化の起こ りやすさは疾患によっても大きく異なるようである。

\section{2) WAS}

$\mathrm{X}$ 染色体上にある WASP（WAS protein）は血液系細胞の みに発現するアクチン細胞骨格調節因子をコードする遺伝 子で, この遺伝子の変異があると易感染性, 湿疹, 血小板 減少を 3 主徴とする免疫不全症を発症する。WAS に対する 遺伝子治療はこれまでに $\gamma \mathrm{RV}$ ベクターを用いて 10 名の患 者に行われ，そのほとんどで易感染性はもとより湿疹や血 小板減少は回復した。ただ，治療を受けた患者のうち 7 名 にLMO2, MECOM, CCND2, PRMD16近傍へのベクター 挿入による白血病が発症し，その内訳として T 細胞性白血 病が 6 名, 急性骨髄性白血病が 3 名 $(2$ 名は $\mathrm{T}$ 細胞白血病 からの二次性発症, 1 名は初発）となっている ${ }^{11} 。$ 一方, 使 用するベクターをレンチウイルス亜科のヒト免疫不全症ウ イルス（HIV）由来のベクター（LVベクター）に変更した 遺伝子治療が欧米で行われ, その結果, 患者の臨床症状は 改善し，また，その挿入部位も治療後 8 年以上を経過した 現在でも polyclonal な状態であり, 一例も白血病の発症を 

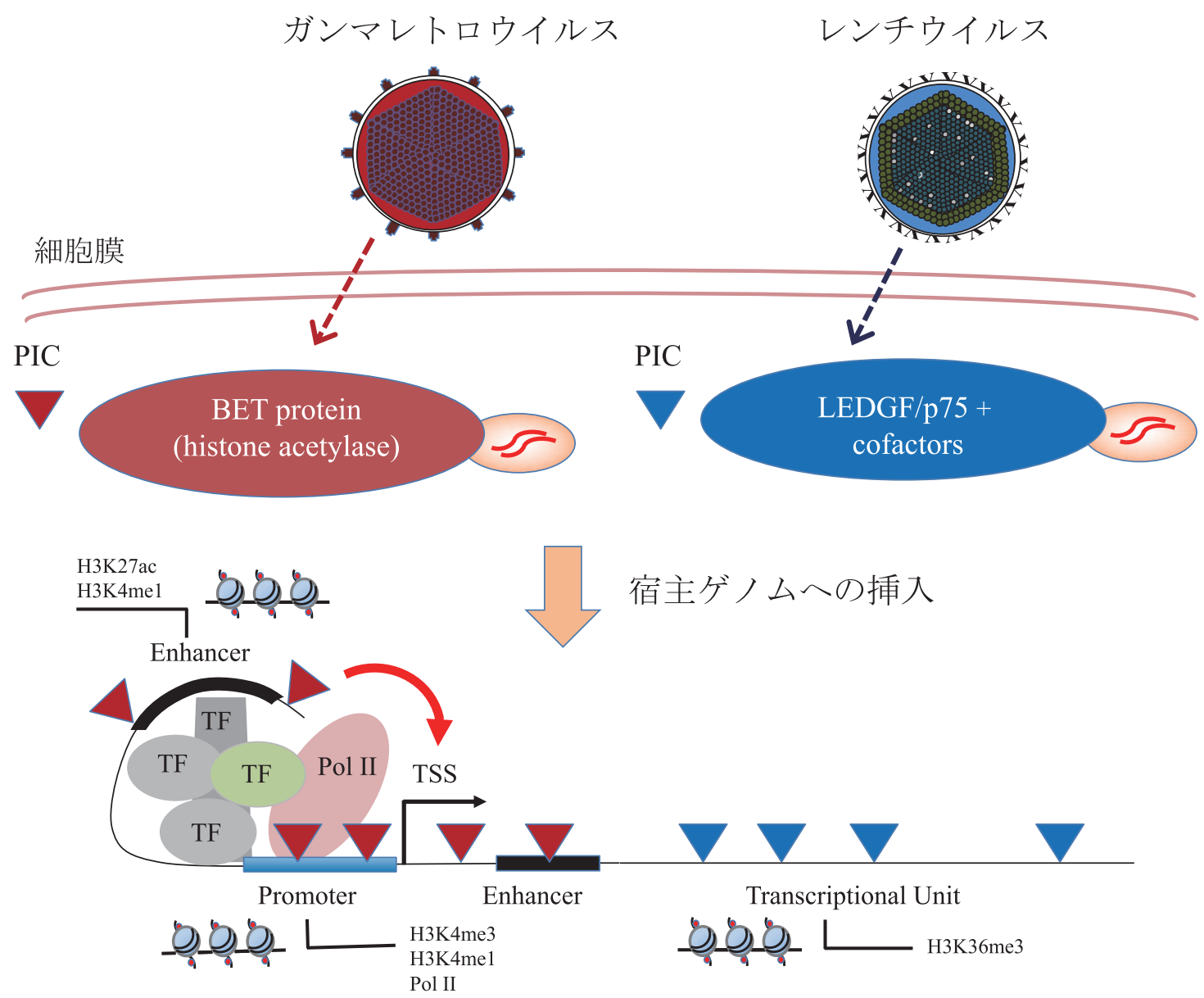

Figure 2. ガンマレトロウイルスとレンチウイルスとの宿主ゲノムへの挿入機構の違い. ガンマレトロウイルスは細胞 質内に侵入後, BET protein と結合することで Pre-integration complex (PIC) を形成する。BET protein はヒストン H3 と結合するので，ガンマレトロウイルスは選択的に promoter/enhancer 領域に挿入される。一方, レンチウイルスは細 胞質内で LEDGF/p75 と結合し, PIC を形成する。この LEDGF/p75 は主に H3K36me3 の修飾を受けた nucleosome と結合するので, レンチウイルスはゲノム全体（Transcriptional unit）に分散して挿入される。

見ていない。

\section{3) $\mathrm{X}$-CGD}

CGD は活性酸素産生に必要な NADPH oxidase の機能異 常により，食細胞が殺菌する際に活性酸素が産生されない ことで炎症反応が遷延する疾患である。なお, NADPH oxidase の構成要素は複数あるが, 我が国では $C Y B B$ がコー ドする gp91phox に異常があるX-CGD が全体の約 8 割を占 める。CGDに対する遺伝子治療はこれまでに $\gamma \mathrm{RV}$ ベク ターを用いて行われているが, 米国や英国, 韓国, 日本で の遺伝子治療ではマウスにリンパ性白血病を発症する Moloney murine leukemia virus (MoMLV) 由来のベクターが 用いられ，ドイッ，スイスでの遺伝子治療ではマウスに赤 白血病を発症する spleen focus-forming virus (SFFV) 由来の ベクターが用いられている。結果, 前者ではこれまでとこ ろ白血病等の造血系異常を発症していないが, 後者では治 療を受けた 4 名全例に骨髄異形成症候群等の造血系異常を 発症し, SFFV の強力な enhancer 活性の影響が示唆されて
いる ${ }^{12}$ 。このため, 現在では LVベクターを用いた遺伝子治 療が行われ，その安全性，有効性が評価されている。

\section{2. ベクターによる挿入部位の違い}

レトロウイルスベクターを用いた遺伝子治療の有効性は 原発性免疫不全症を含む複数の遺伝性疾患において証明さ れているが，その一方でがん関連遺伝子近傍へのベクター 挿入による造血系腫瘍の発症も数多く報告されている。た だ,これは今までのところ $\gamma \mathrm{RV}$ ベクターのみで見られる現 象で, 同じレトロウイルスの LVベクターではその報告は ない。その原因として両者の染色体への挿入機序の違いが 関与していると思われる (Figure 2) ${ }^{13}$ 。

レトロウイルスベクターは感染後, 自らが持つ逆転写酵 素によりゲノム RNAを DNAに変換し, プロウイルスとし て染色体に挿入される。ただ，その際，宿主の核内夕ンパ ク質との結合し, pre-integration complex (PIC) を形成する 必要があるが, $\gamma \mathrm{RV}$ と LVでは異なる核内タンパク質と結 
A

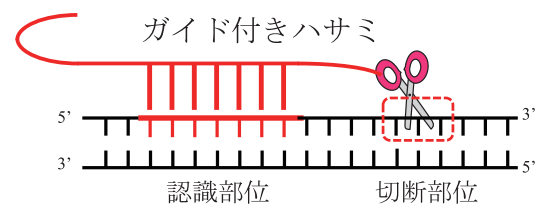

B

ZFNs

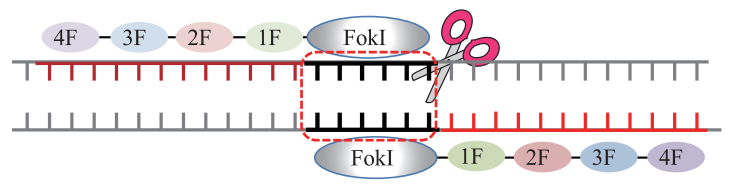

TALENs

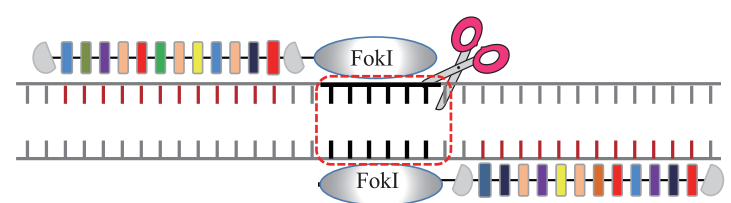

CRISPR/Cas9

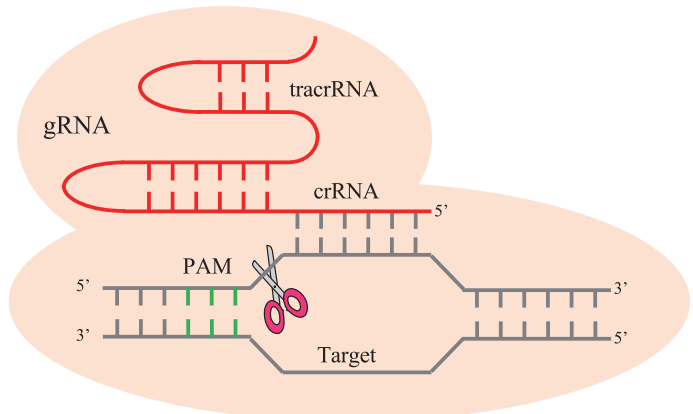

Figure 3. ゲノム編集の原理（A）とその種類（B）

Table 1. ゲノム編集技術の種類と特徴

\begin{tabular}{lccc}
\hline & ZFNs & TALENs & CRISPR/Cas9 \\
\hline 認識 & タンパク/DNA & タンパク/DNA & RNA/DNA \\
ZF: 9 18 塩基 $\times 2$ & TALEN: $15 \sim 20$ 塩基 & 20 塩基の guide RNA \\
特異性 & 中 & 高 & 中 \\
クロマチン構造 & 感受性大 & 感受性大 & 感受性中 \\
メチル化部位 & 感受性大 & 感受性大 & 非感受性 \\
off-target 影響 & 大 & 小 & 中 \\
多遺伝子の対応 & 一遺伝子ごと & 一遺伝子ごと & 同時に複数可能 \\
コスト & 高 & 中 & 低 \\
調整難易度 & 高 & 中 & 低 \\
時間 & (受託業者必要) & (国内にノウハウあり) & ベクター構築に多大な時間 \\
\hline
\end{tabular}

合する。 $\gamma \mathrm{RV}$ ベクターではBET protein (bromo- and extraterminal domain containing protein) と結合し, BET protein C 端にある ET domain とインテグラーゼが結合し， $\mathrm{N}$ 端にある bromodomain が nucleosome のヒストン（H3， H4) と結合することで promoter/enhancer 領域に集中的に挿 入される。一方, LVベクターはLEDGF/p75 (lens epithelium derived growth factor/p75）と結合し, LEDGF/p75 のC 端に ある IBD（integrase-binding domain）とインテグラーゼが結 合し，N 端にある PWWP motif が H3K36me3 の修飾を受け た nucleosome と結合することでゲノム全体 (Transcriptional unit）に分散して挿入されることになる。

\section{3. ゲノム編集技術の種類}

以前より理想的な遺伝子治療は疾患の原因遺伝子そのも のを修復することにあると考えられてきた。ただ，最大の 問題はおよそ 31 億個あるヒ卜塩基の配列から如何に正し く原因遺伝子を探しだし，そこにゲノム編集を加えられる かである。すなわち，正確な「遺伝子配列の認識」とその 部位での「遺伝子切断」を可能にする「ガイド付きハサミ」 


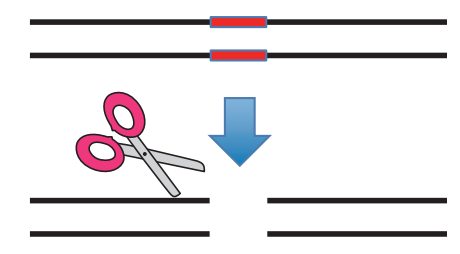

Double strand break

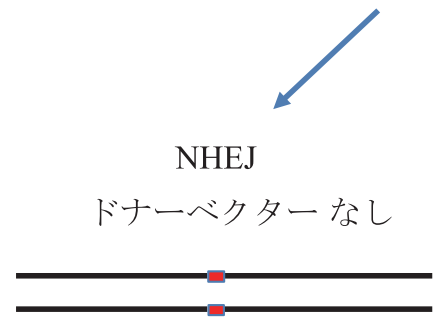

遺伝子破壊

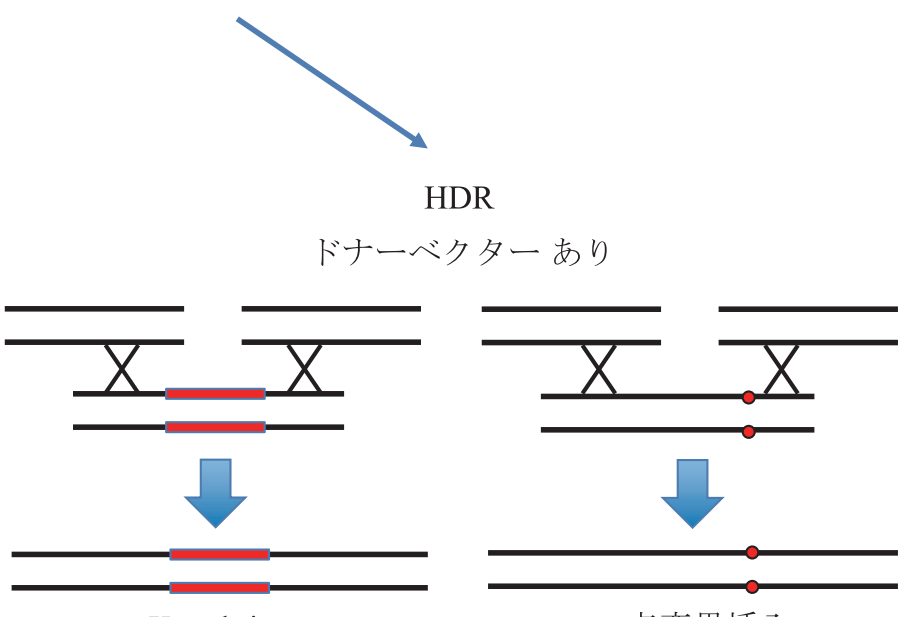

Knock-in
点変異挿入

Figure 4. 遺伝子切断後の変化. 遺伝子切断後, 細胞内のインテグラーゼにてよって修復されるが, その際, 塩基の挿 入・欠損が起こる (NHEJ, 左)。一方, その際にドナーベクターが存在することで, 遺伝子の置換が起こり, ドナーベ クターは挿入される (HDR, 右)。

の開発こそが Gene correction による遺伝子治療の最大の重 要な案件であり（Figure 3A), 仮に 16 塩基を認識するセン サー $\left(4^{16} \doteqdot 43\right.$ 億 $)$ 付きハサミが開発されれば, ヒト塩基 31 億を網羅的に判断し，そこにゲノム編集を加えられること になる。本章では, 現在まで開発され, 臨床応用が期待され る3つのゲノム編集技術を紹介する (Figure 3B, Table 1) ${ }^{14}$ 。

\section{1) Zinc-finger nucleases (ZFNs)}

塩基認識はカスタムデザイン化された zinc-finger protein （ZF）により行われ，ゲノム切断は制限酵素 Fok1 によって 行われる。なお，ひとつの ZFNs は 3〜6 個の ZF を持ち, 各々が 3 個の塩基対を認識することで片アリル 9〜18 個の 塩基を認識することになり（Figure 3 の ZFNs は 4 個の ZF を持ち, $4 \times 3=12$ 塩基を認識する), 認識部位末端より 5〜 7 塩基対を二量体化した Fok1 によって切断する。ただ,一 つの ZF が塩基に対し一対一ではなく，一度に 3 個の塩基 を認識することから，その認識に不確実性を生み，また， そのタンパク構造関係から隣り合う ZF の配列認識にも影 響を与える可能性がある。このため, 至適 ZFNs の合成は 通常の研究室では困難で, 専門業者に委託する場合が多 く，その作製に多額の費用と時間がかかる。

\section{2) Transcription activator-like effector nucleases} (TALENs)

塩基認識は DNA 結合能を有する細菌由来の TALE が行 い, ゲノム切断はFok1 によって行われる。TALE は 34 個 のアミノ酸を 1 繰り返しとする 18 repeat で構成され, この 1 repeat が 1 塩基を認識する (Figure 3 では 14 repeat が示さ れ, 1 box が 1 repeat を示す)。なお, 1 repeat 34 アミノ酸の うち 12 位と 13 位は可変可能で (repeat variable di-residues, RVDs)，このアミノ酸を置換することで各々の塩基結合性 を変えることができる。ZFNsの $1 \mathrm{ZF}$ が 3 個の塩基対を認 識するのに対し, TALENs では 1 repeatが 1 塩基を認識する ことから, その特異性は高く, 異なる配列を認識する offtarget 効果が起こる可能性は極めて小さい。また, その合成 も, 特段, 技術を要しないことから, 比較的広範囲で使用 されている。ただ, ZFNsより分子量が極めて大きいため, $\mathrm{AAV}$ 等のウイルスベクターへの搭載が困難なことが多い。

3) Clustered regularly interspaced short palindromic repeats/CRISPR associated protein 9 (CRSPR/Cas9)

細菌には, 外来より侵入したウイルスやプラスミド DNA をガイドRNA（gRNA）にて認識し, ヌクレアーゼの Cas にて切断する獲得免疫機構があり, この機構をゲノム 編集に応用したが CRISPR/Cas システムである。現在，主 
に使用されているのがII 型の CRSPR/Cas9 で, ヌクレアー ゼとしての Cas9を使用し, 塩基配列を切断する。また, そ の塩基認識は, 対象となる 20 塩基と相補的な CRISPR RNA (crRNA) によって行われ, crRNA はそのリピート配列と相 補的な配列を有する trans-activating crRNA（tracrRNA）を介 して Cas9 と結合している。なお, crRNAと tracrRNAを合 わせて gRNA とよぶ。また, 切断部位は gRNA 直下のプロ トスペーサー隣接モチーフ（PAM）と呼ばれる NGGより 3 塩基対上流となる。このように CRSPR/Cas9 では塩基配 列の認識を gRNA で行うため, その認識をタンパクで行う ZFNs や TALENs と異なり，作製が容易であり，また，一 度に複数の塩基配列を切断する CRISPR/Cas システムを設 計することも可能である。ただ，配列認識を RNA で行う ため TALENs と比べては off-target 効果は高い。

\section{4. 血液細胞を標的としたゲノム編集遺伝子治療}

ゲノム編集技術では, 宿主 DNA の切断後, 細胞自体が 持つライゲースにより DNA 切断面の修復が起こるが, こ の際, 切断面に塩基の追加あるいは欠失が起こり (insertions/deletions: indels), 結果としてフレームシフトに よる機能的タンパク質の発現欠失が起こる。この現象を Non-homologous end joining (NHEJ) とよび, 機能遺伝子の 破壊方法をして行われている（Figure 4 左）。一方, 変異遺 伝子の修復には, ヌクレアーゼによる目的遺伝子の切断と 修復すべき配列を含む一定の長さのドナーテンプレートが 必要で, その相補性をもって宿主遺伝子との置換 (Homology directed repair, HDR あるいは Homologous recombination, HR）が起こる（Figure 4 右）。たた，この現 象は細胞分裂依存的であり, HDRによる遺伝子修復は NHEJによる遺伝子破壊よりその効率は格段に低い。

よって, 現在, ゲノム編集技術による遺伝子治療の主な 標的細胞は，末梢血 $\mathrm{T}$ 細胞であり，これまでに HIV co-receptor の CCR5 を破壊した HIV 感染抵抗性 T 細胞の樹 立 ${ }^{15}$ や chimera antigen receptor $(\mathrm{CAR}) \mathrm{T}$ 細胞療法（CAR- $\mathrm{T}$ 療法）において $\mathrm{T}$ 細胞受容体 $\alpha$ 鎖遺伝子（TCR $\alpha$ chain）を 破壊し, GVHD 発症予防のための universal $\mathrm{T}$ 細胞の樹立を 目指したものである ${ }^{16}$ 。ただ，理想的には造血幹細胞レべ ルでのゲノム編集が望ましく, 現在, ドナーテンプレート の挿入にインテグラーゼ・フリーレンチウイルスベクター (IDLV) や AAV6 ${ }^{17}$ のような非染色体抻入型のウイルスベク ターを用いた基礎的研究が盛んに行われている。

\section{5. ゲノム編集の今後の展開}

今後, ゲノム編集技術をさらに展開し，実際の臨床の場
で活用していくためには，その安全性と倫理性を十分に検 討する必要がある。ただ，ゲノム編集技術は現在も進化し 続けている技術であり, また, その原理も不明瞭な点が多 く, 適切に安全性を評価することは難しい。例えば, ゲノ ム編集技術にて適切な部位の塩基配列が切断されても (on-target)，そこに挿入される indels は一定ではなく，この 切断による転座，欠損等の染色体異常を発生する可能性は 否定できない。さらに, 予期せぬ部位での DNA 切断 (offtarget） は機能遺伝子の破壊や過剩発現を促し, 遺伝子改変 した細胞のよる腫瘍化や自己免疫性疾患の惹起も危惧され る。確かに，現在，これらに対し最も信頼される評価系は 次世代シーケンサー（NGS）を用いた網羅的解析ではある が，その検出感度には限界があり，また，検出する塩基配 列にもバイアスが掛かり, 必ずしも NGSが全ての遺伝子変 化を評価できるわけではない。さらに, 遺伝子導入細胞の 品質は患者への投与という観点から重要で, 例えばドナー テンプレートを挿入する際のウイルスベクターの品質や安 全性, 遺伝子改変に用いられる核酸薬, さらには培養液等 の品質は, 直接, 遺伝子改変細胞の品質に影響を与えるこ とから, 単に遺伝子改変細胞の遺伝子変化を評価するのみ ではなく, 遺伝子改変細胞の品質をその機能面からも評価 する必要がある。

次に，倫理性に関しては，標的細胞として造血幹細胞や 末梢血 T 細胞等を用いた ex vivo 遺伝子は, これまでの Gene additionにおける遺伝子治療と同様，その倫理性は特に問 題はないと思われる。また, 直接, 体内にベクターを投与 する in vivo 遺伝子治療は, 確かに血流等により生殖器に達 し，そこで生殖細胞に感染する可能性も否定はできない が, これまでの in vivo 遺伝子治療の結果から, その可能性 は極めて低く, 対象とする臓器や使用するプロモーターの 選定をすることで実施可能と思われる。

一方, 精子や受精卵等の生殖細胞を標的とした生殖細胞 遺伝子治療はその遺伝子改変自体が次世代に受け継がれ, また，いまだ技術的側面から全ての細胞において同一の遺 伝子改変をもたらすことが難しいことから, 現時点では欧 米を含めて禁止されている。ただ，この議論は単に医師や 研究者のみでなされるべきではなく，患者会等を含めた広 い範囲での論議は必要であることは論を俟たない。

\section{最後に}

この十余年で Gene additionによる遺伝子治療は急速に進 歩し, 現在では遺伝性疾患を含む多くの疾患に対して有効 な治療法としての地位を確立している。その一方で, ベク ターのがん関連遺伝子近傍への挿入による腫瘍の発生や gain-of-function による疾患への不対応は, いまだ,この 
Gene addition による遺伝子治療の大きな問題点として指摘 されている。その解決策として登場してきたゲノム編集技 術は今後の遺伝子治療の流れを大きく変えていくと思われ るが，その現実化にはさらなる技術革新が必要で，また， その倫理的背景はこれまで経験したどの治療より深淵であ ることから，しっかりとした社会的コンセンサスの下に実 施を検討して行く必要がある。

\section{利益相反の開示}

本稿に関連して, 開示すべき COI（Conflict of Interest）関係に ある企業等はない。

\section{文献}

1. 遺伝子治療臨床研究に関する指針（平成 27 年 8 月 12 日 告示)

2. Cicalese MP, Ferrua F, Castagnaro L, et al. Update on the safety and efficacy of retroviral gene therapy for immunodeficiency due to adenosine deaminase deficiency. Blood. 2016; 128: 4554 (Erratum in: Blood 129: 3271, 2017).

3. Hacein-Bey-Abina S, Pai SY, Gaspar HB, et al. A modified $\gamma$-retrovirus vector for X-linked severe combined immunodeficiency. N Engl J Med. 2014; 371: 1407-1417.

4. Aiuti A, Biasco L, Scaramuzza S, et al. Lentiviral hematopoietic stem cell gene therapy in patients with Wiskott-Aldrich syndrome. Science. 2013; 341: 1233151.

5. Cartier N, Hacein-Bey-Abina S, Bartholomae CC, et al. Hematopoietic stem cell gene therapy with a lentiviral vector in X-linked adrenoleukodystrophy. Science. 2009; 326: 818-823.

6. Biffi A, Montini E, Lorioli L, et al. Lentiviral hematopoietic stem cell gene therapy benefits metachromatic leukodystrophy. Science. 2013; 341: 1233158.

7. Cavazzana-Calvo M, Payen E, Negre O, et al. Transfusion inde- pendence and HMGA2 activation after gene therapy of human $\beta$-thalassaemia. Nature. 2010; 467: 318-322.

8. Bainbridge JW, Mehat MS, Sundaram V, et al. Long-term effect of gene therapy on Leber's congenital amaurosis. N Engl J Med. 2015; 372: 1887-1897.

9. Nathwani AC, Reiss UM, Tuddenham EG, et al. Long-term safety and efficacy of factor IX gene therapy in hemophilia B. N Engl J Med. 2014; 371: 1994-2004.

10. Cooper AR, Lill GR, Shaw K, et al. Cytoreductive conditioning intensity predicts clonal diversity in ADA-SCID retroviral gene therapy patients. Blood. 2017; 129: 2624-2635.

11. Braun CJ, Boztug K, Paruzynski A, et al. Gene therapy for Wiskott-Aldrich syndrome--long-term efficacy and genotoxicity. Sci Transl Med. 2014; 6: 227.

12. Siler U, Paruzynski A, Holtgreve-Grez H, et al. Successful Combination of Sequential Gene Therapy and Rescue AlloHSCT in Two Children with X-CGD- Importance of Timing. Curr Gene Ther. 2015; 15: 416-427.

13. Demeulemeester J, De Rijck J, Gijsbers R, Debyser Z. Retroviral integration: Site matters: Mechanisms and consequences of retroviral integration site selection. Bioessays. 2015; 37 : 1202-1214.

14. Gaj T, Sirk SJ, Shui SL, Liu J. Genome-Editing Technologies: Principles and Applications. Cold Spring Harb Perspect Biol. 2016 (review); 8.

15. Wang CX, Cannon PM. The clinical applications of genome editing in HIV. Blood. 2016; 127: 2546-2552.

16. Qasim W, Zhan H, Samarasinghe S, et al. Molecular remission of infant B-ALL after infusion of universal TALEN geneedited CAR T cells. Sci Transl Med. 2017; 9: 2017 (Erratum in: Sci Transl Med 9 (377), 2017)

17. Wang J, Exline CM, DeClercq JJ, et al. Homology-driven genome editing in hematopoietic stem and progenitor cells using ZFN mRNA and AAV6 donors. Nat Biotechnol. 2015; 33: $1256-1263$. 


\title{
Development of gene therapy using genome editing technology
}

\author{
Masafumi Onodera
}

National Center for Child Health and Development Department of Human Genetics

\begin{abstract}
A current definition of gene therapy is the infusion of a therapeutic gene, or cells transduced with the gene, in order to cure or prevent illnesses. This method can be used to add a functional gene into genomes containing a mutated version, which is left unmodified. However, gene therapy cannot be used to treat diseases caused by gain-of-function mutations, and leukemogenesis is often induced by integration of the vector into sites adjacent to proto-oncogenes. On the other hand, gene editing technologies, such as the CRISPR/Cas system, have been developed at a rapid pace and introduced into the field of gene therapy. This article describes the safety, efficacy, and ethics of gene therapy, by focusing on problems inherent to current gene therapy techniques involving gene addition, and the development of future gene therapies using gene correction. (Journal of Hematopoietic Cell Transplantation $7(2): 32-39,2018$. )
\end{abstract}

